\title{
Identification of the bacterial endosymbionts in leaf nodules of Pavetta (Rubiaceae)
}

\author{
Benny Lemaire, ${ }^{1}$ Sandra Van Oevelen, ${ }^{2}$ Petra De Block, ${ }^{3}$ \\ Brecht Verstraete, ${ }^{1}$ Erik Smets, ${ }^{1,4,5}$ Els Prinsen ${ }^{2}$ and Steven Dessein ${ }^{3}$ \\ ${ }^{1}$ Laboratory of Plant Systematics, K.U. Leuven, Kasteelpark Arenberg 31, PO Box 2437, \\ BE-3001 Leuven, Belgium \\ ${ }^{2}$ Laboratory of Plant Growth and Development, University of Antwerp, Department of Biology, \\ Groenenborgerlaan 171, BE-2020 Antwerp, Belgium \\ ${ }^{3}$ National Botanic Garden of Belgium, Domein van Bouchout, BE-1860 Meise, Belgium \\ ${ }^{4}$ Netherlands Centre for Biodiversity Naturalis, PO Box 9517, 2300 RA Leiden, The Netherlands \\ ${ }^{5}$ National Herbarium of The Netherlands, Leiden University, PO Box 9514, 2300 RA Leiden, \\ The Netherlands
}

Correspondence

Benny Lemaire

benny.lemaire@bio.kuleuven.be

\section{INTRODUCTION}

About 500 species of Rubiaceae and Primulaceae have been reported to house bacterial symbionts in leaf nodules or galls (Miller, 1990). In Rubiaceae, nodulating 'bacteriophilous' species are limited to three distantly related genera, i.e. Psychotria sensu stricto (approximately 80 out of 1400 species), Sericanthe (11-12 out of 17 species) and Pavetta. With approximately 350 accepted nodulated species, Pavetta contains the largest number of nodulated species, with $85 \%$ of species in the genus harbouring bacterial endosymbionts within leaf nodules in tropical continental Africa and Asia (Miller, 1990). In Psychotria and Pavetta, bacterial leaf symbiosis was hypothesized to be obligate and cyclic: the presence of the bacterial partner is required

Abbreviations: AU, approximately unbiased; $\mathrm{Bl}$, Bayesian inference; GTR, general time reversible; ML, maximum-likelihood; SEM, scanning electron microscopy; SH, Shimodaira-Hasegawa.

The GenBank/EMBL/DDBJ accession numbers for the sequences reported in this paper are given in Supplementary Table S1 (available in IJSEM Online).

A supplementary figure and a supplementary table are available with the online version of this paper. for host survival (Gordon, 1963) and endosymbionts are retained within the host plant during all stages of its life cycle (von Faber, 1912; Miller, 1990). Although no-one has been able to trace the endosymbionts throughout the complete life cycle of Pavetta, the presence of endosymbionts has been proven in ovule and seed. In Pavetta gardeniifolia, a pair of stipules surrounds young developing inflorescences. Colleters inside the stipules produce mucilage that contains bacteria. These bacteria enter the ovary when the flower buds are initiated and are enclosed in the ovary when the carpel primordia close. The bacteria survive in the ovary (an aril-like tissue at the base of each ovule produces the necessary mucilage) and probably enter the ovule during its ontogeny or through the micropyle during fertilization when a pollen tube enters. Bacteria have also been found in the mucilage between the cotyledons of the embryo in Pavetta seeds (von Teichman et al., 1982).

Over time, several attempts have been made to isolate, cultivate and identify the bacterial endosymbionts in 'bacteriophilous' Rubiaceae, but none have been successful because of the uncultivability of the endosymbionts (e.g. Van Oevelen et al., 2002, 2004). Only recently, the endosymbionts of three Psychotria species have been identified as 
Burkholderia species; based on sequence analysis of the small-subunit (16S) rRNA gene, the endosymbionts were considered to represent novel species, for which the names 'Candidatus Burkholderia calva', 'Candidatus Burkholderia kirkii' and 'Candidatus Burkholderia nigropunctata' were proposed (Van Oevelen et al., 2001, 2002, 2004). Leafnodulating endosymbionts in the other genera of angiosperms remained unknown until now.

The aims of the present molecular study are to identify the bacterial partner in three African nodulated Pavetta species and to address the following questions: 1) are the endosymbionts of Pavetta also Burkholderia species as in Psychotria?; 2) what is the relationship between the endosymbionts of Pavetta and Psychotria?; 3) does each Pavetta species house its own unique endosymbiont?; and 4) how stable is the hostendosymbiont relationship?

\section{METHODS}

Morphological observations. For scanning electron microscopy (SEM), sections through leaf nodules preserved in $70 \%$ ethanol were made using razor blades. The dissected leaves were washed repeatedly in 70\% ethanol and dehydrated in a 1:1 mixture of ethanol and dimethoxymethane (DMM) for $20 \mathrm{~min}$ and in $100 \% \mathrm{DMM}$ for another $20 \mathrm{~min}$. Critical-point dried samples (CPD 030; BAL-TEC) were mounted on aluminium stubs, coated with gold (SPI Module sputter coater; SPI Supplies) and analysed with a JEOL JSM-6360 SEM.

For microtome sections, dehydrated samples were embedded in Technovit 7100 (resin based on hydroxyethyl methacrylate; Heraeus Kulzer). Samples were infiltrated in infiltration medium [Technovit $7100(100 \mathrm{ml})$ and hardener I $(1 \mathrm{~g})]$ for $24 \mathrm{~h}$ at room temperature and transferred to the embedding liquid [infiltration medium $(11 \mathrm{ml})$ and hardener II $(1 \mathrm{ml})$ ], allowing polymerization in a Histoform mould (Heraeus Kulzer). The blocks were hardened at room temperature and at $40{ }^{\circ} \mathrm{C}$. Once removed from the mould, the blocks were heated to $70{ }^{\circ} \mathrm{C}$ and trimmed using razor blades. Sections ( $7 \mu \mathrm{m}$ thick) were made using a rotation microtome (Leica RM2135) and one-way metal knives (Leica DB80L). The sections were stained with toluidine blue $(0.02 \%)$ for $3-5 \mathrm{~min}$, rinsed in distilled water, differentiated in $96 \%$ alcohol and, after drying, mounted in Entellan.

Plant material and taxon sampling. In total, leaf material of three nodulated Pavetta species (10 different accessions) and three nodulated Psychotria species (11 accessions) was provided by the National Botanic Garden of Belgium. Related bacterial sequences of Burkholderia were obtained from the BCCM/LMG Bacteria Collection (Laboratorium voor Microbiologie, Universiteit Gent; http://bccm. belspo.be/about/lmg.php) and GenBank. All species sampled are listed in Supplementary Table S1 (available in IJSEM Online) which gives strain/voucher information, origin and GenBank accession numbers.

DNA extraction, amplification, cloning and sequencing. DNA was extracted from silica-dried material using the E.Z.N.A. HP Plant DNA Mini kit (Omega Bio-Tek). Initially, PCR amplification of the 16S rRNA gene was done with universal primers 16SB and 16SE (Van Oevelen et al., 2001). Amplicons were subjected to BLAST analyses in GenBank. All GenBank sequence homologues belonged to bacteria of the genus Burkholderia. A more specific second reverse primer 16S2 (5'-CAGACTGCGATCCGGACTACGATC-3') was constructed corresponding to position 1262-1285 (relative to Escherichia coli 16S
rRNA gene), avoiding amplification of chloroplast homologues. For $r e c A$ and $g y r B$ amplification primers were used as proposed by Spilker et al. (2009).

Each amplification reaction was performed in $25 \mu$ reaction mix containing $1 \mu \mathrm{l}$ total DNA, $16 \mu \mathrm{l} \mathrm{H}_{2} \mathrm{O}, 2.5 \mu \mathrm{l} 10 \times$ PCR buffer, $0.75 \mu \mathrm{l} 25 \mathrm{mM} \mathrm{MgCl} 2,1 \mu \mathrm{l} 20 \mathrm{mM}$ forward and reverse primers, $2.5 \mu \mathrm{l} 2 \mathrm{mM}$ dNTP and $0.2 \mu \mathrm{l} \mathrm{Taq}$ DNA polymerase.

The PCRs were run on a GeneAmp PCR System 9700 (Applied Biosystems) for 30 cycles starting at $94{ }^{\circ} \mathrm{C}$ for $1 \mathrm{~min}$, followed by denaturation $\left(94{ }^{\circ} \mathrm{C}\right.$ for $\left.60 \mathrm{~s}\right)$, annealing $\left(55,58\right.$ and $58{ }^{\circ} \mathrm{C}$ for $60 \mathrm{~s}$ for $16 \mathrm{~S}$ rRNA, recA and gyrB genes, respectively), extension $\left(72{ }^{\circ} \mathrm{C}\right.$ for $90 \mathrm{~s}$ ) and a final extension $\left(72{ }^{\circ} \mathrm{C}\right.$ for $\left.7 \mathrm{~min}\right)$.

Amplified products were purified for sequencing by using a modification of the Exo/SAP enzyme cleaning protocol (Werle et al., 1994). Exonuclease $1 \quad(0.20 \mu \mathrm{l}$; Fermentas $)$, shrimp alkaline phosphatase $\left(0.15 \mu \mathrm{l}\right.$; Fermentas), SAP-buffer $(2.25 \mu \mathrm{l}$; Fermentas $)$ and $\mathrm{H}_{2} \mathrm{O}$ $(12.40 \mu \mathrm{l})$ were mixed with PCR product $(21 \mu \mathrm{l})$ and incubated at $37{ }^{\circ} \mathrm{C}$ for $15 \mathrm{~min}$ followed by $80{ }^{\circ} \mathrm{C}$ for $15 \mathrm{~min}$.

Amplified 16S rRNA gene products were cloned into a pGEM-T vector (Promega), according to the manufacturer's instructions and transformed into E. coli JM109 by heat shock. Plasmid purification was obtained by using a PureYield Plasmid Miniprep System (Promega). Purified plasmids and PCR products were sent to Macrogen (Seoul, Korea) for sequencing. Sequencing primers for $16 \mathrm{~S}$ rRNA, recA and gyrB genes were the same as for PCR.

Phylogenetic analyses. Sequences were assembled and edited according to Staden et al. (1998). A preliminary sequence alignment was created with Muscle (Edgar, 2004) followed by manual adjustments
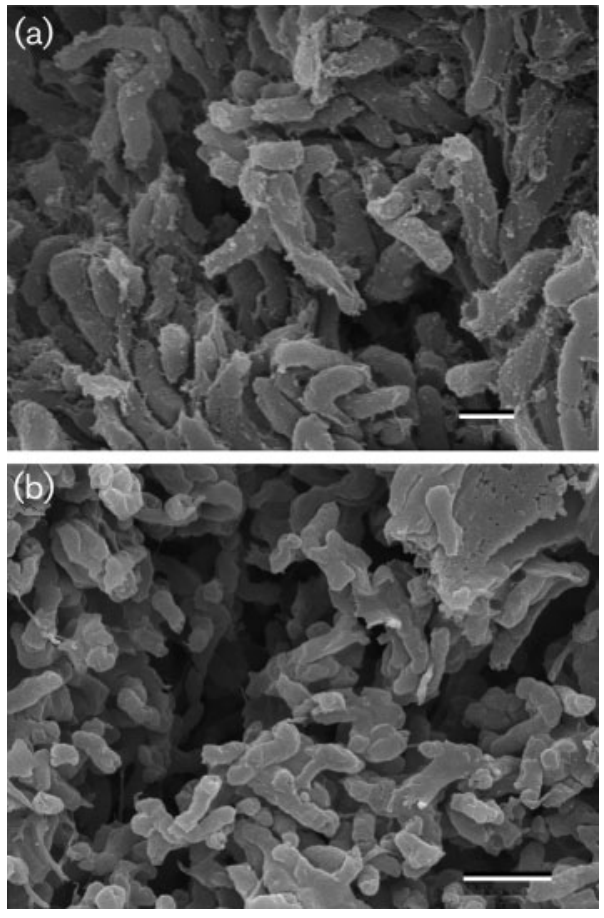

Fig. 1. Micrographs (SEM) of leaf-nodulating endosymbionts of Pavetta schumanniana (accession no. 2001-944257) (a) and Psychotria kirkii (accession no. 2001-036-24) (b). Rod-shaped bacteria without flagella are visible. Bars: $a, 1 \mu \mathrm{m} ; \mathrm{b}, 2 \mu \mathrm{m}$. 
with MacClade 4.04 (Maddison \& Maddison, 2002) resulting in an unequivocal alignment. Phylogenetic trees were estimated using probabilistic methods under both Bayesian and maximum-likelihood (ML) criteria in the CIPRES web portal with separate and combined analyses of the three genes.

ML analyses were performed using RAxML-VI-HPC v2.0 using a general time reversible (GTR)-MIX model of evolution (Stamatakis, 2006). A total of 100 multiple runs were conducted and the tree with the best likelihood was selected as the optimal tree. A multi-parametric bootstrap resampling with 1000 iterations provided bootstrap supports.

Bayesian inference (BI) analyses were performed using MrBayes 3.1 (Huelsenbeck \& Ronquist, 2001; Ronquist \& Huelsenbeck, 2003), running four Markov chains sampling every 100 generations for five million generations. Bayesian analyses were conducted with a GTR model of DNA substitution with gamma-distributed rate variation across invariant sites. This best fitting model of DNA substitution was chosen by performing hierarchical likelihood-ratio tests in MrModeltest v.3.06 (Posada \& Crandall, 1998). Independent models were applied for each of the three partitions (16S rRNA, recA and gyrB genes). Conservatively, $25 \%$ of the first trees sampled were regarded as 'burn-in' and discarded. Convergence of the Markov chains was checked using Tracer v.1.4 (Rambaut \& Drummond, 2007).

Significant incongruence among ML and BI trees of the separate data partitions (16S rRNA, recA and gyrB genes) and the combined datasets were determined using the approximately unbiased (AU; Shimodaira, 2002) and Shimodaira-Hasegawa (SH; Shimodaira \& Hasegawa, 1999) tests. Site-wise log-likelihoods were calculated with PAUP ${ }^{*}$ v.4.0b10 (Swofford, 2002) and used as input for multiscale bootstrap resampling using Consel v.0.1j (Shimodaira \& Hasegawa, 2001) to calculate the $P$-value for each alternative topology.
The pairwise divergence distance between sequences of the concatenated dataset was calculated with the program Geneious 4.8.4 (http://www.geneious.com). The percentage of interspecific and intraspecific nucleotide divergence of Burkholderia species has been visualized in Excel v.11.2.

\section{RESULTS AND DISCUSSION}

\section{Morphological observations of the leaf-nodulating endosymbionts}

For SEM observations of the bacterial endosymbionts within leaf nodules, only fixed material of Pavetta schumanniana was available. The endosymbionts of both Psychotria (Fig. 1a) and Pavetta (Fig. 1b) representatives are clearly visible as rod-shaped bacteria without flagella structures. The length of the endosymbionts varied between 1 and $2 \mu \mathrm{m}$.

\section{Phylogenetic analyses}

To determine the taxonomic position of the bacterial endosymbionts, total DNA of leaf nodules was isolated and amplified using $16 \mathrm{~S}$ universal primers (16SB and 16SE). Direct sequencing of full-length $16 \mathrm{~S}$ rRNA gene for endosymbionts of two Pavetta and one Psychotria species, followed by BLAST searches, revealed that the leafnodulating endosymbionts of Psychotria and Pavetta are closely related to the genus Burkholderia and that each host species is infected by only one bacterial strain. These

Table 1. Comparison of topologies of the $16 \mathrm{~S} r R N A$, recA and gyrB genes and combined datasets under $\mathrm{BI}$ and $\mathrm{ML}$ analyses

$P$-values were obtained from the AU and SH tests for the complete genus Burkholderia and for the reduced Burkholderia glathei-nodulated Burkholderia taxon sampling. Values given in bold indicate rejection of the null hypothesis with $99 \%$ confidence.

\begin{tabular}{|c|c|c|c|c|c|c|c|c|c|}
\hline \multirow[t]{2}{*}{ Analysis } & & \multicolumn{2}{|c|}{ 16S rRNA gene } & \multicolumn{2}{|c|}{$\operatorname{rec} A$} & \multicolumn{2}{|c|}{$g y r B$} & \multicolumn{2}{|c|}{ Combined } \\
\hline & & $\mathrm{AU}$ & SH & $\mathrm{AU}$ & SH & $\mathrm{AU}$ & SH & $\mathrm{AU}$ & SH \\
\hline \multicolumn{10}{|c|}{ Complete taxon sampling } \\
\hline \multirow[t]{4}{*}{ BI } & 16S rRNA gene & 1.0 & 1.0 & $<0.01$ & $<0.01$ & $<0.01$ & $<0.01$ & $<0.01$ & $<\mathbf{0 . 0 1}$ \\
\hline & $\operatorname{rec} A$ & $<0.01$ & $<0.01$ & 0.16 & 0.45 & $<0.01$ & $<0.01$ & $<0.01$ & $<0.01$ \\
\hline & $\operatorname{gyr} B$ & $<0.01$ & $<0.01$ & $<0.01$ & $<0.01$ & 1.0 & 1.0 & $<0.01$ & $<\mathbf{0 . 0 1}$ \\
\hline & Combined & $<0.01$ & $<0.01$ & 0.84 & 0.97 & $<0.01$ & 0.07 & 1.0 & 1.0 \\
\hline \multirow[t]{4}{*}{ ML } & 16S rRNA gene & 1.0 & 1.0 & $<0.01$ & $<0.01$ & $<0.01$ & $<0.01$ & $<0.01$ & $<0.01$ \\
\hline & $\operatorname{rec} A$ & $<0.01$ & $<0.01$ & 0.98 & 0.99 & $<0.01$ & $<0.01$ & $<0.01$ & $<0.01$ \\
\hline & $\operatorname{gyr} B$ & $<0.01$ & $<0.01$ & $<0.01$ & $<0.01$ & 0.99 & 0.99 & $<0.01$ & $<\mathbf{0 . 0 1}$ \\
\hline & Combined & $<0.01$ & $<0.01$ & 0.02 & 0.17 & 0.01 & 0.13 & 1.0 & 1.0 \\
\hline \multicolumn{10}{|c|}{ Burkholderia glathei-nodulated Burkholderia clade } \\
\hline \multirow[t]{4}{*}{ BI } & 16S rRNA gene & 0.53 & 0.49 & $<0.01$ & 0.05 & 0.2 & 0.17 & $<0.01$ & 0.11 \\
\hline & $\operatorname{rec} A$ & $<0.01$ & 0.01 & 0.17 & 0.6 & 0.04 & 0.1 & $<0.01$ & 0.11 \\
\hline & $\operatorname{gyr} B$ & $<0.01$ & $<0.01$ & $<0.01$ & 0.03 & 0.8 & 0.9 & $<0.01$ & $<0.01$ \\
\hline & Combined & 0.52 & 0.8 & 0.8 & 0.8 & 0.2 & 0.17 & 1.0 & 1.0 \\
\hline \multirow[t]{4}{*}{ ML } & 16S rRNA gene & 1.0 & 0.57 & $<0.01$ & 0.12 & 0.45 & 0.54 & $<0.01$ & 0.18 \\
\hline & $\operatorname{rec} A$ & $<0.01$ & $<0.01$ & 0.54 & 0.73 & 0.02 & 0.15 & 0.03 & 0.09 \\
\hline & gyrB & $<0.01$ & $<0.01$ & 0.04 & 0.16 & 0.59 & 0.73 & 0.01 & 0.03 \\
\hline & Combined & 1.0 & 0.57 & 0.57 & 0.83 & 0.45 & 0.54 & 1.0 & 1.0 \\
\hline
\end{tabular}


16S rRNA gene sequences obtained from endosymbionts of leaf-nodulating species were used to design a primer (16S2) for specific amplification of endosymbiotic DNA, prohibiting any organelle homologues. The partial $16 \mathrm{~S}$ rRNA gene sequences of the endosymbionts of 10 Pavetta and 11 Psychotria accessions confirmed the bacterial

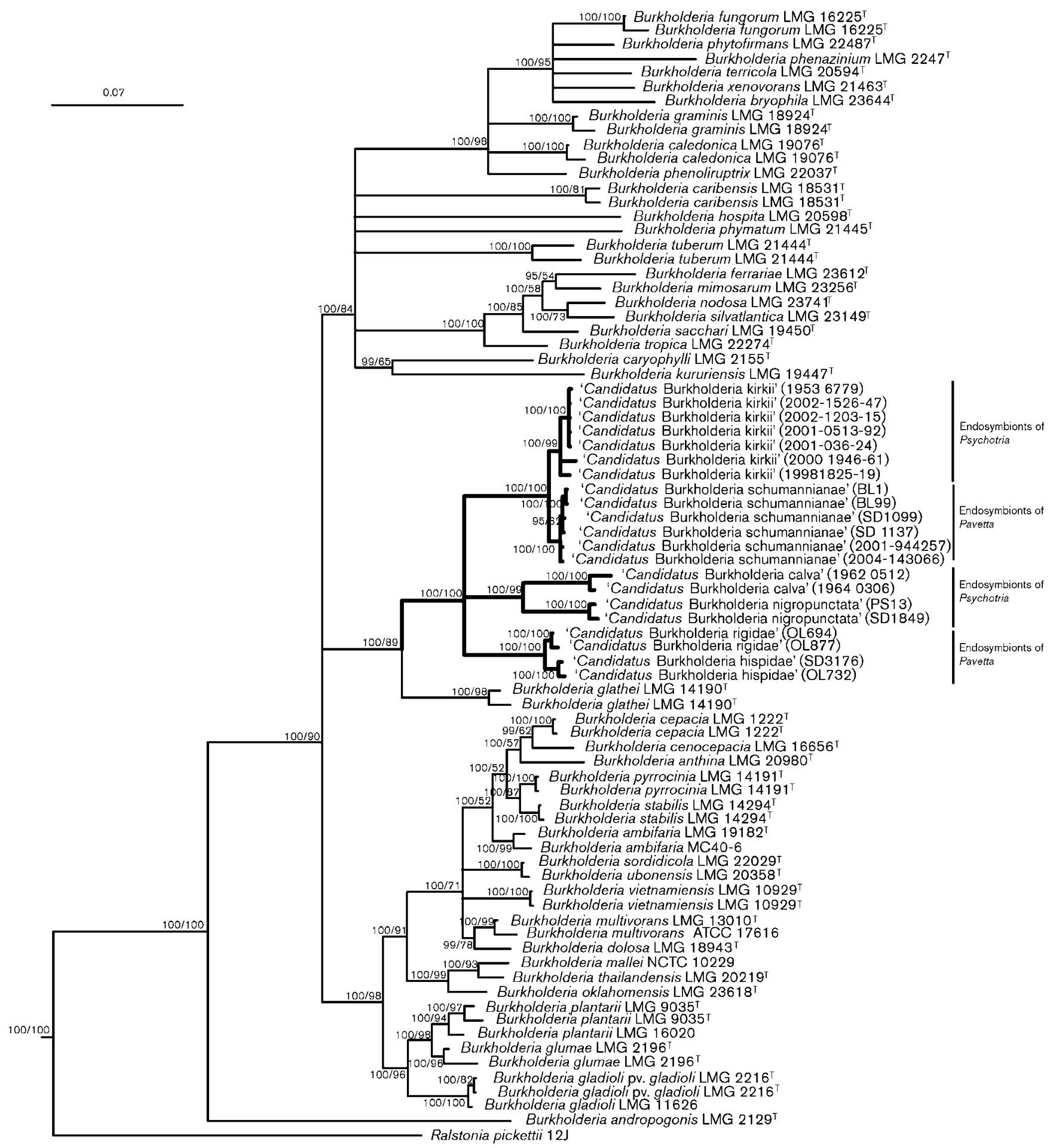

Fig. 2. Phylogenetic relationships within the genus Burkholderia based on phylogenetic analysis of $16 \mathrm{~S} \operatorname{rRNA}, \operatorname{rec} A$ and gyr $B$ gene sequence data. Support values of BI (Bayesian posterior probabilities)/ML (bootstrap values) analyses are given at the nodes. Branches of leaf-nodulating endosymbionts are shown in bold. Bar, 0.07 substitutions per site. 
identity as Burkholderia and were used for further phylogenetic analyses.

As well as the 16S rRNA gene region, data for two widely used housekeeping genes ( $r e c A$ and $g y r B$ ) have been added for phylogenetic analyses. This three-loci dataset comprised 78 Burkholderia strains, including 21 nodulating endosymbionts. Ralstonia pickettii was used as outgroup. The $16 \mathrm{~S}$ rRNA, recA and gyrB gene fragments were 1139, 554 and $617 \mathrm{bp}$, respectively. Overall, phylogenetic analyses of the separate datasets showed roughly the same topologies, with similarly supported clades. However, the phylogenetic trees based on $\operatorname{rec} A$ and $\operatorname{gyr} B$ genes show improved resolution over the 16S rRNA gene tree. The 16S rRNA gene-based tree appeared to be less resolved with conflicts at a low taxonomic level, compared to the $\operatorname{rec} A$ and $\operatorname{gyr} B$ trees. These incongruencies can be attributed to differences in divergence rates between the genes. The resolution of the $16 \mathrm{~S}$ rRNA gene-based phylogeny is considerably lower than those of the $r e c A$ and $g y r B$ topologies, whereas the latter two datasets provided more congruent relationships with higher resolution at the interspecific level. The phylogenies of the separate datasets (16S rRNA, recA and gyrB genes) are shown in Supplementary Fig. S1 (available in IJSEM Online).

The AU and SH tests (Table 1) confirm significant incongruencies between the phylogenetic markers, regardless of the optimality criterion used. However, a restriction in taxon sampling to the Burkholderia glathei-nodulated endosymbiont clade resolved most of the incongruencies. These results might indicate that conflicts between the datasets can be explained by a lack in phylogenetic signal within: 1) the slow evolving $16 \mathrm{~S}$ rRNA gene; and 2) the relative short $r e c A$ and $g y r B$ sequences.

The combined analysis showed a remarkable increase in resolution and provided well-supported relationships between closely and more distantly related taxa. The combined $50 \%$ majority rule consensus tree obtained by $\mathrm{BI}$ and
ML analysis is shown in Fig. 2. Overall, the phylogenetic relationships of the combined analyses were in agreement with recent taxonomic studies, which are based on multilocus sequence typing analyses (Spilker et al., 2009; Vanlaere et al., 2009). The three-gene dataset showed well-supported relationships between closely related Burkholderia species providing a robust framework to determine the phylogenetic position of potentially new species. Leaf-nodulating endosymbionts of the three Pavetta and three Psychotria species were included within the extensive Burkholderia dataset. A maximum supported clade with endosymbionts of leafnodulating Psychotria and Pavetta species was recovered as a sister group to Burkholderia glathei, the most closely related species with a validly published name. This sister group relation was also recovered in a previous phylogenetic study (Van Oevelen et al., 2004). The endosymbionts of Pavetta hispida formed a sister group to the endosymbionts of Pavetta rigida. The endosymbionts of Psychotria calva were the closest neighbours of the endosymbionts of Psychotria nigropunctata. The endosymbionts of Psychotria kirkii formed a sister group to the endosymbionts of Pavetta schumanniana. These phylogenetic relationships make the endosymbionts of Pavetta and Psychotria paraphyletic and the idea that bacterial leaf nodulation originated independently within the two nodulating genera is rejected, which is a somewhat surprising result. The two nodulated genera Pavetta and Psychotria are distantly related, belonging to different subfamilies of the Rubiaceae. Furthermore, the morphology of the bacterial nodules in Pavetta and Psychotria is different: in Psychotria, the nodular pores open on the abaxial leaf surface, whereas in Pavetta the nodular pores are situated on the adaxial leaf surface (Miller, 1990; Fig. 3a-c). The latter two considerations lead to the assumption that bacterial leaf nodule symbiosis originated independently in these two genera.

However, our results suggest that bacterial leaf symbiosis is not the result of a single infection event in the nodulated ancestor of Psychotria and Pavetta, followed by strict
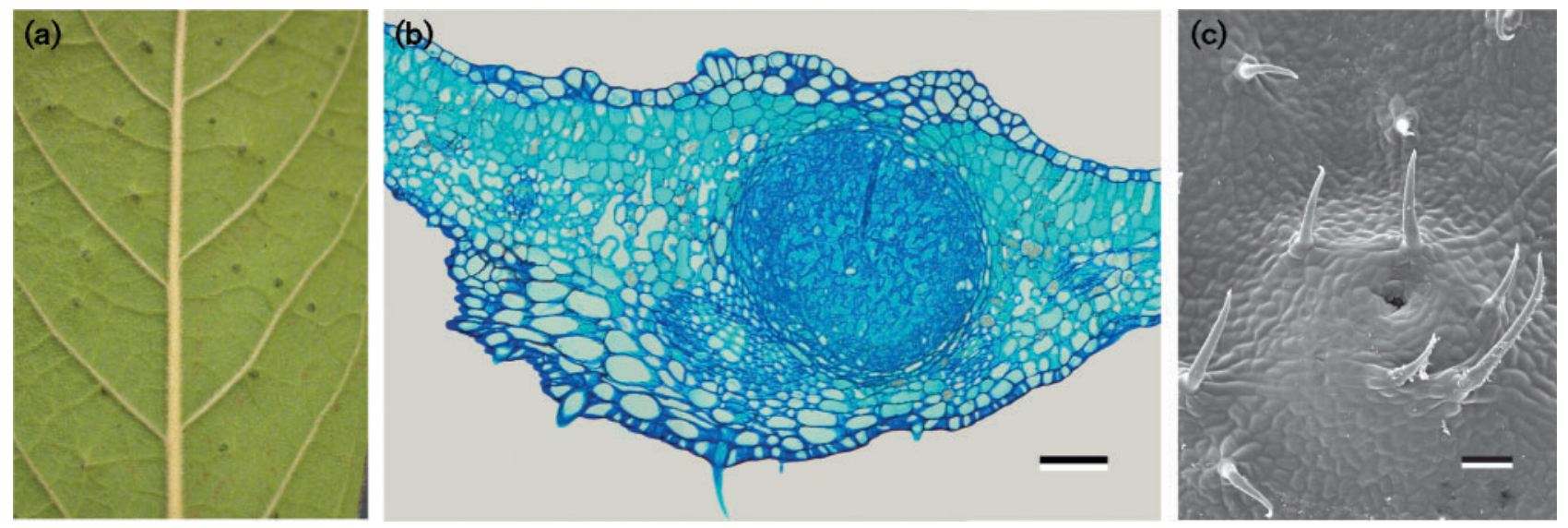

Fig. 3. Bacterial leaf nodule on leaf of Pavetta schumanniana. (a) Abaxial leaf surface with bacterial galls. (b) Cross LM section through a young leaf with bacterial leaf gall; in later stages the gall will completely fill the width of the leaf. (c) Micrograph (SEM) of bacterial leaf gall on adaxial surface of leaf; note the pore in the middle of the gall. Bars, $100 \mu \mathrm{m}$. 


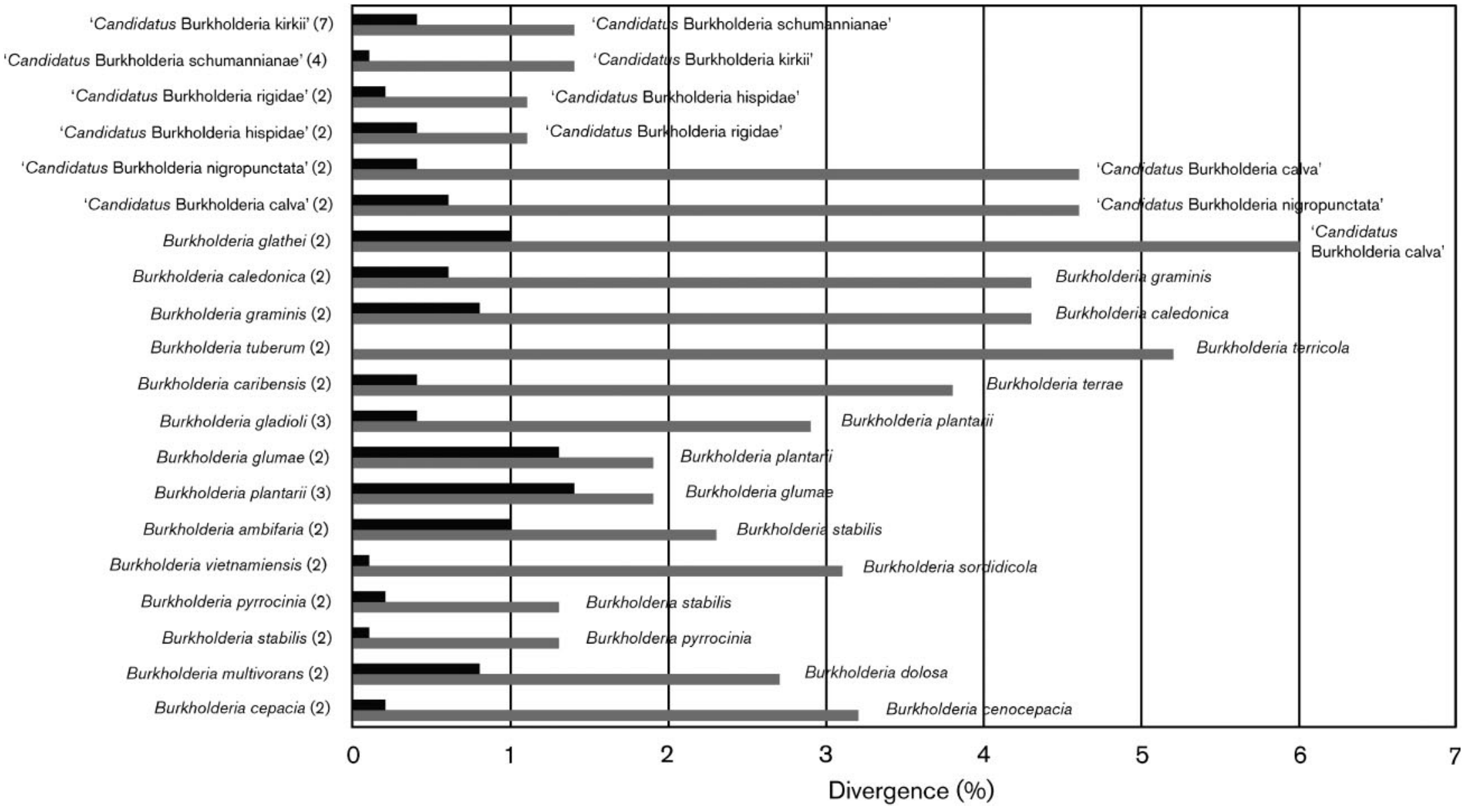

Fig. 4. Sequence divergence of the concatenated dataset (16S rRNA, recA and gyrB genes). Grey bars show the divergence between a Burkholderia species (listed to the left) and its closest relative (listed to the right). Black bars represent the intraspecific variation. The number of duplicates used for each taxon is given in parentheses. 
co-speciation between plant and bacteria. The phylogenetic analyses indicate at least two infections in both leafnodulating genera Psychotria and Pavetta. These results are in contrast to those of Van Oevelen et al. (2004), who found that bacterial leaf nodulation in Psychotria was the result of a single infection event and proposed co-speciation between plant and bacteria.

The leaf-nodulating endosymbionts from different accessions of the studied Pavetta and Psychotria species have been sequenced to verify the stability of the hostendosymbiont relationship and to describe intraspecific variation. Is each host plant species infected by the same endosymbiont strain or can we detect sequence heterogeneity? Phylogenetic analyses showed that each nodulating plant species was colonized by its own unique Burkholderia endosymbiont: six well-supported monophyletic groups of endosymbionts were identified, each occurring exclusively in a single host species (Fig. 2). Moreover, bacterial $16 \mathrm{~S}$ rRNA gene clones from Pavetta hispida (accession OL732), Pavetta rigida (accession OL694) and Pavetta schumanniana (accession SD1099) were obtained and comparison of the sequences from each plant species showed identical or nearly identical 16S rRNA genes (99.8-100\% DNA similarity). Small $16 \mathrm{~S}$ rRNA gene sequence differences are most probably the result of the occurrence of multiple copies of the 16S rRNA gene within the bacterial genome. Our results therefore indicate that each species is housing only a single bacterial endosymbiont.

The sequence divergence within the nodulated endosymbionts was calculated, resulting in homogeneous molecular groups with low intraspecific sequence variation compared to their interspecific sequence variation (Fig. 4). This pattern of specificity between bacteria and hosts provides molecular evidence for the hypothesis of relatively recent vertical transmission of endosymbionts at the intraspecific level, which has been postulated previously by Miller (1990) and Van Oevelen et al. (2004). This host specificity suggests that endosymbionts are genetically separated as a consequence of the closed nature of the symbiotic cycle in nodulating Pavetta (von Teichman et al., 1982) and Psychotria species (von Faber, 1912; Miller, 1990), and that every endosymbiont is adapted and specialized to the different ecological niches provided by their specific host plants. The evolutionary and ecological properties of the leaf-nodulating endosymbionts proposed in this study should justify the separation of the endosymbiont into species according to their host species.

Efforts to cultivate the endosymbionts of Pavetta on growth media have not yet been successful, suggesting their dependence on an unidentified plant-specific substance (S. Van Oevelen, personal communication). According to Murray \& Stackebrandt (1995), uncultured organisms should be recorded under the provisional status Candidatus. We propose to use specific epithets of the plant host species as specific epithets for these candidate Burkholderia species.

\section{Description of 'Candidatus Burkholderia hispidae', 'Candidatus Burkholderia rigidae' and 'Candidatus Burkholderia schumannianae'}

'Candidatus Burkholderia hispidae' (his.pi'dae. N.L. gen. n. hispidae of hispida, referring to the specific epithet of the host plant) [(Betaproteobacteria, genus Burkholderia); NC; G-; R; NAS (GenBank nos HQ849122, HQ849178, HQ849231), oligonucleotide sequence complementary to unique region of $16 \mathrm{~S}$ rRNA gene 5'-GGGGATTCATTTCCTTAGTAATGTAGCTAACGCGTG-3', oligonucleotide sequence complementary to unique region of recA $5^{\prime}$-CCAGATTCGCATAAAGATTGGTGTGATGTTCGGCAATCCG-3', oligonucleotide sequence complementary to unique region of gyrB gene 5'-CACCGAGAATCGCGGCACGGAAGTGTATTTCATGGCCGACG-3'; S (Pavetta hispida, leaf galls)]. Lemaire et al., this study.

'Candidatus Burkholderia rigidae' (ri.gi'da.e. N.L. gen. n. rigidae of rigida, referring to the specific epithet of the host plant) [(Betaproteobacteria, genus Burkholderia); NC; G-; R; NAS (GenBank nos HQ849120, HQ849176, HQ849229), oligonucleotide sequence complementary to unique region of 16S rRNA gene 5'-GGGGATTCGTTTCCTTAGTAACGTAGCTAACGCGTG-3', oligonucleotide sequence complementary to unique region of recA 5'-CCAGATTCGCATGAAGATCGGCGTGATGTTCGGCAATCCG-3', oligonucleotide sequence complementary to unique region of gyrB gene 5'-CACCGAGAATCGTGGCACGGAAGTGCATTTCATGGCCGACG-3'; S (Pavetta rigida, leaf galls)]. Lemaire et al., this study.

'Candidatus Burkholderia schumannianae' (schu.man.ni.a' nae. N.L. gen. n. schumannianae of schumanniana, referring to the specific epithet of the host plant) [(Betaproteobacteria, genus Burkholderia); NC; G-; R; NAS (GenBank nos HQ849124, HQ849180, HQ849233), oligonucleotide sequence complementary to unique region of $16 \mathrm{~S}$ rRNA gene 5'-GGTCTTCGGATTGTAAAGCACTTTTGTCCGG$3^{\prime}$, oligonucleotide sequence complementary to unique region of recA 5'-GGAACACGCGCTCGACGTGCAATACGCGGGCAAGCTT-3', oligonucleotide sequence complementary to unique region of $\operatorname{gyrB}$ gene $5^{\prime}$-AGCGAAGCAAGTGCTGCATCCGAACGTGTTTCATGCGGTG-3'; S (Pavetta schumanniana, leaf galls)]. Lemaire et al., this study.

\section{ACKNOWLEDGEMENTS}

The authors thank Professor Dr P. Vandamme of the University of Ghent for helpful discussions and critical reading of the manuscript. Professor Dr E. Robbrecht of the National Botanic Garden of Belgium is acknowledged for his excellent assistance and support in this project. Bart Jacobs of the University of Leuven is acknowledged for his help with the incongruence tests used in this study. We also thank Mr H. Lekeux, Mr J. Stallaert, Mr J. Van Eeckhoudt and Ms V. Leyman, who are responsible for the collection of the living Rubiaceae in The National Botanic Garden of Belgium, for their help and devotion in growing plants of our study group. This work was supported by the Institute for the Promotion of Innovation by Science and Technology in Flanders (IWT Vlaanderen, no. 71488). General financial support was provided by a grant of the Research 
Program of the Fund for Scientific Research - Flanders (Belgium) (FWO - Vlaanderen, G.0343.09N) and the K.U. Leuven (OT/05/35).

\section{REFERENCES}

Edgar, R. C. (2004). MUSCLE: multiple sequence alignment with high accuracy and high throughput. Nucleic Acids Res 32, 1792-1797.

Gordon, J. F. (1963). The nature and distribution within the plant of the bacteria associated with certain leaf-nodulated species of the families Myrsinaceae and Rubiaceae. $\mathrm{PhD}$ thesis, Imperial College, University of London, UK.

Huelsenbeck, J. P. \& Ronquist, F. (2001). MRBAYES: Bayesian inference of phylogenetic trees. Bioinformatics 17, 754-755.

Maddison, D. R. \& Maddison, W. P. (2002). MacClade 4: Analysis of Phylogeny and Character Evolution, Version 4.01. Sunderland, Massachusetts: Sinauer Associates.

Miller, I. M. (1990). Bacterial leaf nodule symbiosis. Adv Bot Res 17, 163-234.

Murray, R. G. E. \& Stackebrandt, E. (1995). Taxonomic note: implementation of the provisional status Candidatus for incompletely described procaryotes. Int J Syst Bacteriol 45, 186-187.

Posada, D. \& Crandall, K. A. (1998). MODELTEST: testing the model of DNA substitution. Bioinformatics 14, 817-818.

Rambaut, A. \& Drummond, A. J. (2007). Tracer v1. http://beast.bio.ed. ac.uk/Main_Page

Ronquist, F. \& Huelsenbeck, J. P. (2003). MrBayes3: Bayesian phylogenetic inference under mixed models. Bioinformatics 19, 1572-1574.

Shimodaira, H. (2002). An approximately unbiased test of phylogenetic tree selection. Syst Biol 51, 492-508.

Shimodaira, H. \& Hasegawa, M. (1999). Multiple comparisons of log-likelihoods with applications to phylogenetic inference. Mol Biol Evol 16, 1114-1116.

Shimodaira, H. \& Hasegawa, M. (2001). CONSEL: for assessing the confidence of phylogenetic tree selection. Bioinformatics 17, 1246-1247.

Spilker, T., Baldwin, A., Bumford, A., Dowson, C. G. Mahenthiralingam, E. \& LiPuma, J. J. (2009). Expanded multilocus sequence typing for Burkholderia species. J Clin Microbiol 47, 26072610.

Staden, R., Beal, K. \& Bonfield, J. (1998). The Staden Package. In Computer Methods in Molecular Biology, vol. 132, pp. 115-130. Edited by S. Misener \& S. Krawetz. Totowa, NJ: Humana Press.

Stamatakis, A. (2006). RAxML-VI-HPC: maximum likelihood-based phylogenetic analyses with thousands of taxa and mixed models. Bioinformatics 22, 2688-2690.

Swofford, D. L. (2002). PAUP*: Phylogenetic analysis using parsimony (and other methods), version 4. Sunderland, MA: Sinauer Associates.

Van Oevelen, S., Prinsen, E., De Wachter, R. \& Robbrecht, E. (2001). The taxonomic value of bacterial symbiont identification in African Psychotria (Rubiaceae). Syst Geogr Plants 71, 557-563.

Van Oevelen, S., De Wachter, R., Vandamme, P., Robbrecht, E. \& Prinsen, E. (2002). Identification of the bacterial endosymbionts in leaf galls of Psychotria (Rubiaceae, angiosperms) and proposal of 'Candidatus Burkholderia kirkii' sp. nov. Int J Syst Evol Microbiol 52, 2023-2027.

Van Oevelen, S., De Wachter, R., Vandamme, P., Robbrecht, E. \& Prinsen, E. (2004). 'Candidatus Burkholderia calva' and 'Candidatus Burkholderia nigropunctata' as leaf gall endosymbionts of African Psychotria. Int J Syst Evol Microbiol 54, 2237-2239.

Vanlaere, E., Baldwin, A., Gevers, D., Henry, D., De Brandt, E., LiPuma, J. J., Mahenthiralingam, E., Speert, D. P., Dowson, C. \& Vandamme, P. (2009). Taxon K, a complex within the Burkholderia cepacia complex, comprises at least two novel species, Burkholderia contaminans sp. nov. and Burkholderia lata sp. nov. Int J Syst Evol Microbiol 59, 102-111.

von Faber, F. C. (1912). Das erbliche Zusammenleben von Bakterien und tropischen Pflanzen. Jahrb Wiss Bot 54, 285-375.

von Teichman, I., Robbertse, P. J. \& van der Merwe, C. F. (1982). Contributions to the floral morphology and embryology of Pavetta gardeniifolia A. Rich. Part 2. The ovule and megasporogenesis. S Afr J Bot 1, 22-27.

Werle, E., Schneider, C., Renner, M., Völker, M. \& Fiehn, W. (1994). Convenient single-step, one tube purification of PCR products for direct sequencing. Nucleic Acids Res 22, 4354-4355. 